\title{
Agama dan Alam dari Perspektif Arne Naess
}

\author{
Barnabas Ohoiwutun ${ }^{\text {a, } 1}$ \\ ${ }^{\text {a }}$ Sekolah Tinggi Filsafat Seminari Pineleng \\ ${ }^{1}$ bertoemesce@ymail.com
}

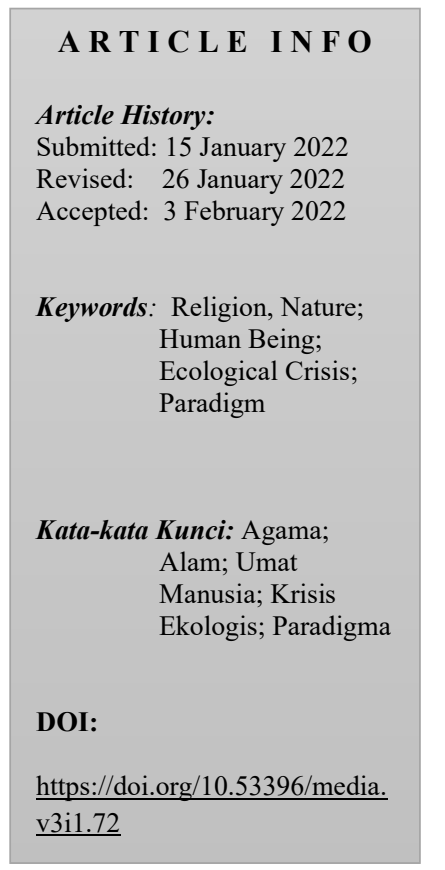

ABSTRACT:
This article aims to explain on Arne Naess' notion of relation between religion
and nature. For Naess, relation between religion and nature has double face. On
the one hand, religion is a good source for human being in understanding nature
and himself. Religion teaches man how to creates a mutual relation with nature.
On the other hand, religion is also the source of ecological crisis since through
biblical interpretation which is anthropological oriented gives man knowledge
and power to control even exploits nature wantonly. Therefore, to stop
ecological crisis we need to shift our anthropological interpretation to an
ecological interpretation. Using descriptive and analysis method, this study
hopes to contribute on understanding of Naess' concept on relation between
religion and nature.

ABSTRAK:

Artikel ini bertujuan menjelaskan konsep Naess tentang relasi antara agama dan alam. Bagi Naess, relasi antara agama dan alam memiliki wajah ganda. Di satu pihak, agama adalah sumber yang baik bagi manusia dalam memahami alam dan dirinya. Agama mengajarkan manusia bagaimana menciptakan hubungan yang saling menguntungkan dengan alam. Di lain pihak, agama adalah juga sumber krisis ekologis karena melalui interpretasi biblis yang bersifat antroposentris memberikan kepada manusia pengetahuan dan kuasa untuk mengontrol bahkan mengeksploitasi alam secara sewenang-wenang. Demikian, guna mengatasi krisis ekologis kita perlu beralih dari penafsiran antroposentrik kepada penafsiran ekologis. Menggunakan metode deskriptif dan analisis, studi ini berharap berkontribusi pada pemahaman akan konsep Naess tentang relasi agama dan alam.

\section{Copyright $\odot$ 2022, Author}

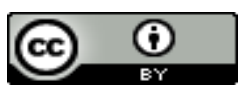

This work is licensed under a Creative Commons Attribution 4.0 International License

\section{Pendahuluan}

Sejak akhir tahun 1960-an dan awal tahun 1970-an muncul dua kecenderungan dalam menanggapi meningkatnya krisis ekologis. Kecenderungan pertama beranggapan bahwa krisis ekologis berakar pada masalah ekonomi, politik dan teknologi. Demikian, dibutuhkan pendekatan ekonomis, politis, dan teknologis guna mengatasi krisis tersebut. Tren kedua berpandangan bahwa krisis ekologis tidak saja berkaitan dengan masalah teknis, tetapi bersumber terutama pada dimensi nilai (filsafat dan agama). Oleh karena itu, mengatasinya diperlukan jalan keluar yang menyeluruh, yakni perubahan paradigma dan 
peralihan gaya hidup. ${ }^{1}$ Termasuk di dalam perubahan paradigma itu adalah perubahan penafsiran teks-teks Kitab Suci oleh kaum beragama supaya lebih bersifat ekologis.

Itu berarti ada hubungan erat antara agama dan alam. Dasarnya, karena agama menyediakan ajaran-ajaran tentang alam dan manusia dan hubungan keduanya. Tidak usah heran, selain menimba inspirasi pada pemikiran Barukh Spinoza dan Mahatma Gandhi, Naess, seperti banyak filsuf dan pejuang lingkungan hidup lain, juga banyak berguru kepada pemikiran Timur, khususnya Hinduisme dan Buddhisme, dalam merumuskan dan membentuk pemikiran ekosofinya. Dari Hinduisme, misalnya, Naess memahami bahwa alam itu suci dan manusia adalah bagian integral dari alam. Ada hubungan saling tergantung di antara manusia dan alam. Demikian, tugas manusia adalah menjadi penjaga dan pemelihara bagi alam dan makhluk lain. Pertanyaannya, apakah hubungan agama dan alam dalam pandangan Arne Naess?

Tulisan ini berupaya menjawab pertanyaan tersebut dari perspektif ekosofi atau filsafat lingkungan hidup. Metode yang dipakai adalah metode deskripsi dan Analisa. Metode deskripsi dipakai untuk menjelaskan pandangan Naess tentang agama bersumber pada tulisan-tulisannya tentang alam. Metode Analisa dimanfaatkan untuk menarik dan membahas hubungan agama dan alam. Demi mencapai tujuan tersebut, artikel ini akan mengikuti skema pembahasan berikut: bagian pertama membahas paham Naess mengenai agama. Bagian kedua, menguraikan pandangan Naess tentang alam. Bagian ketiga berisikan upaya menunjuk hubungan agama dan alam.

\section{Naess tentang Agama}

Naess mengaku diri sebagai orang yang tidak beragama. ${ }^{2}$ Barangkali karena itu, ia tidak menulis buku atau artikel khusus tentang agama. Kendati demikian, dari tulisantulisannya dapat dijejaki dan ditemukan pandangannya tentang agama dalam kaitan dengan alam dan manusia karena ia mendasarkannya pada pemikiran Barukh Spinoza, Mohandas Gandhi, Hinduisme dan Buddhisme.

Dalam artikelnya Spinoza and the Deep Ecology Movement, Naess berpandangan bahwa kendati tidak melepaskan diri sepenuhnya dari iman Yahudinya akan Allah yang transenden, sebagaimana tampak jelas dalam bagian kelima bukunya, Ethics, paham Allah ${ }^{3}$ yang dikembangkan Spinoza adalah Allah yang imanen. ${ }^{4}$ Bagi Spinoza, tulis Naess, Allah itu imanen. Secara konstan Allah sedang menciptakan dunia dengan menjadi kekuatan kreatif di dalam alam. Seluruh ciptaan terlibat dalam proses penciptaan tersebut. ${ }^{5}$ Basis tekstual dari teori imanensi Spinoza ini ditemukan dalam bagian pertama buku Ethics.

\footnotetext{
${ }^{1}$ Arne Naess, Ecology, Community and Lifestyle: Outline of an Ecosophy, 1. ed., repr (Cambridge: Cambridge Univ. Press, 1998), 163.

${ }^{2}$ Arne Naess, Life's Philosophy (Georgia, USA: The University of Georgia Press, 2002), 7-8.

${ }^{3}$ Menurut Naess, beberapa murid Spinoza menyamakan konsep Allah dalam pemikiran Spinoza dengan Allah dalam pengertian modern. Hal ini tidak tepat. Allah yang dimaksudkan di sini adalah Allah atau Alam (Deus sive Natura) yang memiliki dua aspek, yakni sebagai pencipta (natura naturans) dan yang diciptakan (natura naturata). Lihat Arne Naess, "Spinoza and the Deep Ecology Movement," in The Selected Works of Arne Naess, Edited by Harold Glasser and Alan Drengson, vol. X (The Netherlands: Springer, 2005), 402.

${ }^{4}$ Naess, 403.

${ }^{5}$ Naess, Life's Philosophy, 8.
} 
Dalam IP nomor 36, Spinoza menulis, “Apapun yang mengada mengungkapkan dalam cara terbatas dan tertentu esensi atau sifat Allah (P25Cor), artinya (IP34) apapun yang mengada mengungkapkan dalam cara terbatas dan tertentu kuasa Allah." ${ }^{6}$ Menurut Naess, teks ini memerlihatkan bahwa Allah menyatakan esensi atau kuasanya tidak dalam cara lain selain melalui eksistensi dari setiap pengada. Dengan kata lain, Allah sebagai pencipta tidak lain daripada aspek kreativitas yang didistribusikan secara tidak merata dan saling terkait dalam diri pengada-pengada. Demikian, bagi Naess, dari perspektif ekologis harus disimpulkan bahwa karena pengada-pengada kreatif adalah ekspresi dari Allah atau Alam, maka seluruh makhluk hidup memiliki nilai intrinsik. ${ }^{7}$ Dan karena seluruh makhluk bernilai pada dirinya, maka setiap makhluk hidup perlu dicintai, dijaga dan dipelihara.

Dari tulisan yang sama Naess juga menimba gagasan Gandhi tentang kesatuan manusia dan alam. Mengutip Gandhi, Naess menulis, "Saya percaya akan advaita (nondualitas). Saya percaya akan kesatuan mendasar manusia dan dalam hal ini, semua yang hidup. Oleh karena itu, saya percaya bahwa jika seorang manusia mencapai kekudusan, seluruh dunia menang bersama dia, jika seorang manusia gagal, seluruh dunia gagal untuk itu."8 Bagi Naess, kutipan ini menunjukkan bahwa Gandhi mengakui hak dasar yang dimiliki setiap makhluk, yakni hak untuk hidup dan berkembang. ${ }^{9}$ Demikian, yang dibutuhkan bukan kekerasan, melainkan sikap bela rasa, cinta dan perlindungan terhadap setiap makhluk. Karena kekerasan selain melukai bahkan bisa membunuh juga menghalangi manusia untuk mewujudkan realisasi diri dan kesatuannya dengan seluruh makhluk.

Konsep Gandhi tentang kesatuan seluruh ciptaan, tanpa kekerasan dan realisasi diri sesungguhnya bersumber pada Hinduisme, khususnya teks Bhagavadgita. Dalam Bhagavadgita 6:29 dituliskan demikian: "Mereka yang dilengkapi dengan yoga memandang semua dengan mata jujur, melihat Atman (Self) dalam seluruh makhluk dan seluruh makhluk dalam Atman". Tidak usah heran, cukup sering Naess mengutip ayat itu dalam tulisantulisannya, seperti dalam Ecology, Community and Lifestyle, Spinoza dan the Deep Ecology Movement, Ecosophy T: Deep Versus Shallow Ecology, and In Sceptical Wonder. Naess mengutip ayat itu secara lengkap tidak dengan maksud untuk menganjurkan pencapaian penghentian dan dari perwujudan dunia, tetapi untuk tindakan ekologis. Dalam Ecology, Community and Lifestyle, Naess mengutip ayat tersebut guna menggambarkan kaitan erat antara jalan tanpa kekerasan dan filsafat keseluruhan dan kesatuan. ${ }^{10}$ Dalam artikel Spinoza and the Deep Ecology Movement, Naess mengutip ayat ini untuk memperkuat penjelasannya tentang realisasi diri dalam paham Spinoza. ${ }^{11}$ Menurut Naess, Self yang dimaksudkan adalah dia yang dewasa yang tidak dapat menghindari identifikasi diri dengan seluruh makhluk hidup, melihat dirinya dalam setiap makhluk. Orang seperti ini melihat segalanya di dalam

\footnotetext{
${ }^{6}$ Terkutip dalam Naess, "Spinoza and the Deep Ecology Movement," 404.

${ }^{7}$ Naess, 404.

${ }^{8}$ Terkutip dalam Arne Naess, “The Long-Range Deep Ecology Movement," in The Selected Works of Arne, Edited by Harold Glasser and Alan Drengson, vol. X (The Netherlands: Springer, 2005), 60.

${ }^{9}$ Arne Naess, "Self Realization: An Ecological Approach to Being in the World," in The Ecology of Wisdom, Edited by Alan Drengson and Bill Devall (Berkeley: Counterpoint, 2009), 90.

${ }^{10}$ Naess, Ecology, Community and Lifestyle, 194.

${ }^{11}$ Naess, "Spinoza and the Deep Ecology Movement," 415.
} 
dirinya dan dirinya di dalam semua yang lain. Mengutip Bhagavadgita, Naess menegaskan bahwa sesuatu itu adalah Atman $\left(\right.$ Self). ${ }^{12}$

Dalam Ecosophy T: Deep versus Shallow Ecology, Naess mengutip ayat yang sama dengan komentar demikian: "Realisasi diri dalam [bentuk] tertinggi adalah, seperti saya lihat, pengalaman yang matang akan kesatuan dalam keanekaragaman [seperti] yang digambarkan dalam ayat di atas". ${ }^{13}$ Naess juga merujuk pada ayat tersebut dalam komentarnya pada In Sceptical Wonder. Di sana ia menegaskan kembali tiga gagasan yang memainkan peranan penting dalam pandangan etisnya, yakni: realisasi diri, solidaritas dengan seluruh makhluk dan tanpa kekerasan. Naess menulis. "Penguatan solidaritas dan tanpa kekerasan tergantung pada penguatan dan perluasan proses identifikasi". ${ }^{14}$ Proses identifikasi adalah kemampuan melihat Self di mana-mana. Rumusan ini masih membawa pengaruh dari Advaita Vedanta, tetapi dengan makna yang berbeda. Dalam Advaita Vedanta, realisasi diri dari identitas Atman dan Brahman merupakan pengalaman penyelamatan tertinggi yang dicapai melalui meditasi. ${ }^{15}$ Menurut ekologi-dalam, realisasi diri, kesatuan dan tanpa kekerasan (ahimsa) menyatakan penerimaan akan pluralitas yang disatukan dengan aksi politik demi pemeliharaan dan pelestarian terhadap alam.

Inspirasi dari Buddhisme, terutama datang melalui pemikiran Soto Zen Dogen. Pengaruh Dogen terutama tampak dalam pandangan Naess tentang realisasi diri. Naess bahkan banyak bergantung pada tulisan Dogen untuk menjelaskan apa yang ia maksudkan dengan melampaui dualisme subjek-objek dalam proses realisasi diri. Dalam Gestalt Thinking and Buddhism, Naess mengutip Dogen sebagai berikut: "Rumput, pohon, bangsa, dan tanah, semua tanpa kecuali mencapai pencerahan". ${ }^{16}$ Pengakuan akan sifat Buddha pada seluruh makhluk mengizinkan manusia mengalami bela rasa dengan seluruh makhluk. Selain, realisasi diri, pengaruh Dogen juga terlihat dalam gagasan Naess tentang nilai intrinsik. Dalam bagian akhir 'Gestalt Thinking and Buddhism", Naess menghubungkan ontologi pengalaman spontanitas dengan ontologi nilai. Di sana, Naess mendiskusikan sebuah tulisan Yasuaki Nata berjudul "The Practical Value of Dogen's View of Nature" (tidak diterbitkan) dan pemakaian dua istilah Jepang oleh Nara, yakni inochi dan kuyo. ${ }^{17}$ Secara literer, inochi berarti hidup atau nilai hidup. Nara mencatat bahwa paham kaum Buddhis mengenai tidak melukai menyatu dengan Budaya Jepang melalui inochi. Namun,

\footnotetext{
${ }^{12}$ Dalam Hinduisme, Atman berarti diri yang abadi. Atman menunjuk pada diri yang melampaui ego atau diri palsu. Sering itu menunjuk kepada "roh" atau "jiwa" dan mengindikasikan diri sejati yang mendasari keberadaan kita. DI sini Atman dipahami sebagai sesuatu yang spiritual ketimbang sebagai ada material. Dengan demikian, terdapat dimensi yang kuat dari Hinduisme yang menekankan sikap lepas bebas dari dunia dan mempromosikan praktik seperti matiraga. Lihat Gavin Flood, "Hindu Concepts," 2009, https://www.bbc.co.uk/religion/religions/hinduism/concepts/concepts_1.shtml.

${ }^{13}$ Terkutip dalam Knut A. Jacobsen, "Bhagavadgita, Ecosophy T, and Deep Ecology," in Beneath the Surface, Critical Essays in the Philosophy of Deep Ecology, Edited by Eric Katz, Andrew Light, and David Rothenberg. (Cambridge, Massachusetts: The MIT Press, 2000), 243.

14 Terkutip dalam Jacobsen, 243.

${ }^{15}$ Brahman adalah Bahasa Sanskrit yang menunjuk kepada kekuatan transenden yang melampaui alam dan karena itu sering diterjemahkan sebagai "Tuhan" kendati keduanya tidak identik. Brahman adalah kekuatan yang mendasari dan mendukung segala sesuatu. Oleh sebagian penganut Hindu, kekuatan tersebut diidentikkan dengan Self (Ãtman), sementara yang lain mengganggap sebagai sesuatu yang berbeda dari Self. Gavin Flood, "Hindu Concepts."

${ }^{16}$ Arne Naess, "Gestalt Thinking and Buddhism," in The Ecology of Wisdom, Edited by Alan Drengson and Bill Devall (Berkeley: Counterpoint, 2008), 196.

${ }^{17}$ Deane Curtin, "A aState of Mind Like Water: Ecosophy T and the Buddhist Tradition," in Beneath the Surface, Critical Essays in the Philosophy of Deep Ecology Edited by Eric Katz, Andrew Light and David Rothenberg (Cambridge, Massachusetts: The MIT Press, 2000), 256-57.
} 
tidak melukai, seperti dijelaskan Nara, tidak terbatas hanya pada komitmen untuk tidak melukai makhluk berperasaan. Inochi berarti tidak melukai seluruh pengada. Luasnya pengertian inochi akan mudah dipahami jika dikaitkan dengan kebiasaan Jepang tentang kuyo. Kuyo adalah perayaan kenangan untuk menebus kekerasan yang dilakukan terhadap seluruh pengada. Nara mengutip contoh dari perayaan tahunan untuk belut yang ditunjukkan oleh para pemilik restoran dan para pelanggan karena mengambil inochi belut. ${ }^{18} \mathrm{Kuyo}$ mewajibkan seseorang untuk mengakui bahwa pemakan mengada dalam hubungan dengan belut. Perayaan ini tidak terbatas pada benda-benda hidup saja. Naess menulis, "Di masa Endo, para ibu rumah tangga dan anak-anak gadis setiap rumah tangga diharuskan melakukan kuyo karena penggunaan atau pengrusakan yang tidak perlu dengan perasaan menyesal, syukur, dan dengan doa. Kuyo juga dilakukan untuk jam tua, boneka bermain, sumpit, teh-whiski, dan lain-lain". ${ }^{19}$ Singkatnya, dalam paham tradisional, alam mencakup semua: manusia, hewan, tumbuhan pun benda-benda. Semua mengada karena dipandang sebagai bagian dari alam. Demikian, karena nilai intrinsik dan kesatuan itu, setiap makhluk bahkan pengada perlu dijaga dan dilindungi keberadaannya.

Meski memberi inspirasi, agama juga menjadi sumber kerusakan dan kehancuran dalam alam. Dalam bukunya Ecology, Community and Lifeseyle, Naess berpandangan bahwa hal itu berakar teristimewa pada pemahaman dan penafsiran yang keliru atas teksteks Kitab Suci. Naess menunjuk beberapa teks Kitab Suci yang dijadikan dasar biblis sikap penaklukan manusia atas alam. Teks pertama adalah Kejadian 1:28. Dalam ayat ini tampaknya Allah menghendaki dan memberi kuasa kepada manusia untuk menaklukkan bumi dan mengisi dengan keturunannya, kendati hal itu tidak berarti manusia bebas bertindak sesuka hatinya. Namun, teks ini dipakai untuk memperkuat kesombongan manusia dan sikap merendahkan dan mengeksploitasi alam. ${ }^{20}$

Teks lain yang juga dijadikan rujukan adalah "lalu firman-Nya kepada manusia itu. "Karena engkau mendengarkan perkataan istrimu dan memakan dari buat pohon itu, yang telah Kuperintahkan kepadamu ... semak duri dan rumput duri yang akan dihasilkannya bagimu, dan tumbuh-tumbuhan di padang akan menjadi makananmu" (Kejadian 3:17-18). Menurut Naess, beberapa orang menyimpulkan bahwa makhluk hidup seperti semak duri kurang dapat dihargai karena diciptakan setelah kejatuhan manusia dalam dosa. Setelah kejatuhan manusia dalam dosa, kualitas alam berkurang. Kualitas yang kurang ini dijadikan alasan untuk membenarkan sikap jijik manusia terhadap alam. ${ }^{21}$

\section{Naess tentang Alam}

Apa makna alam dalam pandangan Naess? Dalam artikelnya Spinoza and Attitude Toward Nature, Naess berusaha menjawab pertanyaan tersebut dengan merujuk pada paham Spinoza tentang alam. Fokusnya, pandangan Spinoza tentang alam serentak menarik kesejajarannya dengan pemikiran ekologi-dalam. Titik tolaknya adalah konsep Spinoza tentang Deus sive Natura. Gagasan ini, menurut Naess, berbicara tentang imanensi Tuhan

\footnotetext{
${ }^{18}$ Naess, "Gestalt Thinking and Buddhism," 201-2.

${ }^{19}$ Naess, 202.

${ }^{20}$ Naess, Ecology, Community and Lifestyle, 183-84.

${ }^{21}$ Naess, 186.
} 
di dalam alam, seperti ditulis Spinoza, "Allah adalah imanen, bukan penyebab transenden dari segala sesuatu" (IP 18). ${ }^{22}$ Sebagai penyebab, Allah tidak bisa dipisahkan kecuali secara konseptual dari pengada-pengada partikular. Ia tidak berdaya tanpa esensi pengada-pengada partikular. Tanpa esensi pengada-pengada partikular, Allah tidak ada. Sebaliknya, tanpa Allah, kita adalah ketiadaan. Dalam rumusan lain, bisa dikatakan bahwa Allah atau Alam tidak dapat bereksistensi tanpa pengada-pengada partikular yang terbatas. Sebagai natura naturans, Allah adalah imanen di dalam alam sebagai natura naturata. Bertolak dari gagasan Spinoza tentang Deus sive Natura, Naess menarik beberapa kesimpulan sebagai berikut: ${ }^{23}$

Pertama, karena alam adalah ekspresi Allah, maka mengikuti Spinoza, Naess memahami alam sebagai yang kreatif, inklusif, dan hidup dalam arti luas. Alam itu sempurna, tidak kurang, tidak lebih. Alam sempurna tidak dalam arti sempit, tidak juga karena bermanfaat atau karena indah. Alam sempurna pada dirinya dan bukan karena melayani kebutuhan manusia. Alam dan setiap pengada bernilai pada dirinya dan bukan karena bermanfaat bagi manusia. Singkatnya, alam dan seluruh isinya, baik yang hidup maupun tidak hidup, memiliki nilai intrinsik.

Kedua, semua hal saling terhubung. Ada semacam jaringan relasi internal yang menghubungkan semua pengada. Meminjam istilah Barry Commoner, Naess menulis, "Segala sesuatu terhubung dengan semua yang lain." Setiap pengada dibentuk dan berkembang melalui interaksi dengan yang lain. Tidak ada satupun dari pengada yang terlepas dan terasing sepenuhnya dari hubungan ini. Mengambil jarak dan menjauh dari alam dan jaringan relasi ini, berarti menjauhkan seseorang atau sesuatu dari bagian yang membentuk dirinya. Ekosofi fokus dengan pokok ini, yakni alam dan seluruh makhluk yang saling terhubung. ${ }^{24}$

Ketiga, seluruh alam itu hidup dan merupakan satu kesatuan. Setiap pengada berjuang untuk bertahan dan mengembangkan esensinya yang khusus. Upaya dasar untuk bertahan tidak semata-mata usaha untuk beradaptasi dengan rangsangan dari luar. Itu adalah upaya membentuk lingkungan hidup. Upaya yang berhasil menghasilkan unit-unit organisme baru yang lebih luas. Spinoza menyebut proses ini dengan istilah conatus atau self-preservation. Naess menyebut usaha ini sebagai realisasi diri (self-realization). Naess berpendapat, istilah realisasi lebih baik dan tepat dibandingkan istilah pemeliharaan diri (self-preservation), karena self-realization menegaskan keaktifan dan kreativitas, sementara self-preservation diri menunjuk pada sikap pemeliharaan pasif. Juga karena self-realization tidak saja menunjuk pada upaya untuk mempertahankan diri tetapi juga usaha dan kemampuan untuk mewujudkan potensi diri melalui identifikasi dengan alam dan pengada-pengada lain. Demikianlah, Naess menulis bahwa selain self-realization, istilah yang sepadan ialah "pemenuhan diri" (self-fulfilment), "perwujudkan potensi seseorang" (realizing one's potentials) atau "pengungkapan diri”" (express one's self). ${ }^{25}$

\footnotetext{
${ }^{22}$ Arne Naess, "Spinoza and Attitudes Toward Nature," in The Selected Works of Arne Naess, Edited by Harold Glasser and Alan Drengson, vol. X (The Netherlands: Springer, 2005), 383.

${ }^{23}$ Naess, 387-91.

${ }^{24}$ Naess, Ecology, Community and Lifestyle, 164.

${ }^{25}$ Naess, "Spinoza and the Deep Ecology Movement," 415.
} 
Keempat, karena segala sesuatu di dalam alam adalah ekspresi Tuhan, maka semuanya memiliki hak untuk melakukan apa yang berasal dari kekuatannya. Bedanya, bila Spinoza berbicara tentang hak binatang, Naess berbicara tentang hak seluruh makhluk. Menurut Spinoza, "Hak itu yang mereka [binatang] miliki dalam relasi dengan kita, kita miliki dalam relasi dengan mereka" (IVP37 Sch1). ${ }^{26}$ Sedangkan, Naess berpendapat, tidak adil menganggap hak untuk hidup dan berkembang hanya milik manusia semata. Ini adalah hak universal. Tidak ada spesies makhluk hidup tertentu memiliki hak hidup lebih dibanding spesies lain. Naess menulis:

\begin{abstract}
Hak semua bentuk [hidup] untuk hidup merupakan sebuah hak universal yang tidak dapat diukur. Tidak ada satupun spesies makhluk hidup yang mempunyai lebih hak hidup dan berkembang ini dibanding spesies lain. Barangkali ini bukan jalan terbaik mengungkapkan hal ini untuk mengatakan bahwa ada sebuah hak - hak yang setara untuk semua bentuk hidup - guna mengembangkan kemampuan spesifiknya. "Kesetaraan" yang menganjurkan semacam pengukuran adalah menyesatkan. ${ }^{27}$
\end{abstract}

Kelima, setiap pengada memiliki hak setara untuk hidup dan berkembang dan bernilai pada dirinya. Alhasil, pemakaian kekerasan oleh manusia terhadap makhluk lain tidak dapat dibenarkan. Manusia tidak mempunyai hak khusus untuk membunuh dan melukai. Dalam bahasa Gandhi, karena hidup itu satu dan semua makhluk memiliki hak setara untuk hidup dan berkembang, maka kekerasan tidak pernah dapat dibenarkan. Dasarnya, selain melukai makhluk lain, kekerasan juga menghalangi kemungkinan manusia mewujudkan dirinya.

Keenam, sebaliknya, sikap yang perlu dikembangkan adalah mencintai dan berlaku baik terhadap alam dan makhluk lain. Dengan kata lain, yang perlu dikembangkan adalah rasa cinta dan memiliki ekosferik (ecospheric belonging), yakni rasa memiliki terhadap alam dan makhluk lain. Dari sisi ekologis, kesatuan itu dinyatakan dalam tindakan identifikasi diri dengan alam dan pengada-pengada lain. Proses identifikasi ini menuntun kepada alam secara lebih dekat dan mendalam, sekaligus pengenalan dan kecintaan akan keunikan makhluk lain. Semakin besar identifikasi diri, semakin besar empati kita terhadap seluruh ekosfer. Ketika memiliki empati, tidak ada kepura-puraan dan orang akan menginginkan yang baik dan berguna bagi alam. ${ }^{28}$

\title{
Hubungan Agama dan Alam
}

Dalam bukunya The Sacred Canopy, Peter L. Berger, seperti dikutip oleh Dylan Reaves, menegaskan bahwa dunia dan masyarakat sementara berada dalam sekularisasi. Secara sederhana sekularisasi dipahami sebagai penghapusan otoritas religius. ${ }^{29}$ Tegasnya, sekularisasi adalah "proses di mana bidang-bidang [kehidupan] masyarakat dan kebudayaan disingkirkan dari dominasi institusi dan simbol-simbol agama". ${ }^{30}$ Dengan kata lain, menurut Berger, sekularisasi perlahan akan melemahkan bahkan menyingkirkan peran agama dalam

\footnotetext{
${ }^{26}$ Terkutip dalam Naess, "Spinoza and Attitudes Toward Nature," 390.

${ }^{27}$ Naess, Ecology, Community and Lifestyle, 166.

${ }^{28}$ Naess, 168 .

${ }^{29}$ Dylan Reaves, "Peter Berger and the Rise and Fall of the Theory of Secularization," Denison Journal of Religion 11, article 3 (2012): 11.

${ }^{30}$ Terkutip dalam Reaves, 11.
} 
kehidupan bersama. Pandangan Berger ini, seperti diakui Berger sendiri, terbukti tidak benar karena kenyataannya agama masih tetap memainkan peranan penting dalam kehidupan bersama dewasa ini. Peranan dan pengaruh itu tampak tidak saja dalam bidang politik, sosial, tetapi juga di bidang hak-hak asasi, keadilan sosial, gerakan perdamaian dan lingkungan hidup. ${ }^{31} \mathrm{Hal}$ itu tampak secara jelas juga dalam pandangan Naess tentang agama. Pertanyaannya, apakah hubungan agama dan alam dalam pandangan Naess?

\section{Agama: Sumber Inspirasi dan Pedoman}

Dalam diagram gerakan ekologi-dalamnya, Naess menempatkan agama dan filsafat pada level pertama karena agama dan filsafat menyediakan nilai, prinsip dan pandangan yang menjadi dasar atau basis bagi manusia dalam memandang alam, dirinya dan relasinya dengan sesama dan alam. Dalam artikelnya berjudul The Basics of The Deep Ecology Movement, Naess menulis: "Platform gerakan ekologi-dalam dapat dilandaskan pada agama atau filsafat, termasuk etika". ${ }^{32}$ Kutipan ini dengan jelas memerlihatkan bahwa, bagi Naess, agama merupakan sumber inspirasi dan pemberi arah bagi setiap tindakan manusia dalam relasinya dengan alam.

Tidak mengherankan Naess membangun pemikiran ekosofinya dengan belajar dan berguru kepada pemikiran agama-agam lain. Dari Spinoza yang dipengaruhi oleh Yudaisme, dan Buddhisme, Naess menimba inspirasi bahwa seluruh makhluk bahkan semua pengada bernilai pada dirinya. Demikian, sepatutnya alam dan seluruh isinya tidak dirusak dan dihancurkan, melainkan dijaga, dipelihara dan dilestarikan keberadaannya. Sementara dari Gandhi dan Hinduisme, Naess belajar bahwa alam perlu dihormati dan dirawat karena kita adalah satu kesatuan dan bahwa setiap makhluk memiliki hak yang sama untuk hidup dan berkembang serta mewujudkan dirinya. Oleh karena itu, sikap yang perlu dikembangkan bukan kekerasan, melainkan solidaritas dan non-violence karena kekerasan selain merusak juga menghalangi manusia untuk mewujudkan dirinya.

Cara pandang Naess ini sesungguhnya bukan hal baru. Menurut Henryk Skolimowski, ini sesungguhnya merupakan hal yang lazim karena salah satu karakteristik kosmologi (baru) adalah bercorak spiritual. Maksudnya amat menekankan dan menghargai aspek spiritual dari alam. ${ }^{33}$ Bahwasanya alam itu bernilai, suci, baik dan diciptakan Tuhan karena itu sepantasnya dicintai dan dipelihara. Cara pandang lazimnya ditemukan dalam ajaran-ajaran agama dan kearifan lokal. Dengan kata lain, agamalah sumber pandangan tentang kesucian alam dan paham mengenai bagaimana seharusnya manusia membangun relasi yang baik dan harmonis dengan alam.

Yudaisme, misalnya, mengenal dua prinsip etis lingkungan hidup, yakni tzáar bá alei chayim ("penderitaan dari makhluk hidup") bal tashchit ("jangan merusak"). Menurut Eric Katz, prinsip tzáar bá alei chayim mungkin merupakan prinsip yang paling penting

\footnotetext{
${ }^{31}$ Reaves, 17-18.

32 Arne Naess, "The Basic of Deep Ecology Movement," in The Ecology of Wisdom, Edited by Alan Drengson and Bill Devall (Berkeley: Counterpoint, 2008), 106.

${ }^{33}$ Uraian lebih lengkap lihat Henryk Skolimowski, Eco-Philosophy, Designing New Tactics Fo Living (London: Marion Boyars Publishers LTD, 1981), 33-35.
} 
dalam Yudaisme terkait relasi manusia dan binatang. Prinsip ini mensyaratkan sikap bela rasa terhadap seluruh binatang. Manusia memiliki kewajiban memelihara dan memperhitungkan penderitaan binatang yang hidup di sekitarnya. Prinsip kedua (bal tashchit) mengatur larangan perusakan yang sewenang-wenang atas seluruh entitas alam, hewan dan tumbuhan, dan bahkan artefak karya manusia. Sumber prinsip ini terdapat dalam Kitab Ulangan 20:19-20 yang berbicara tentang larangan merusak tumbuh-tumbuhan pada saat perang dan kondisi normal. ${ }^{34}$

Dalam tradisi Gereja Katolik, ajaran tentang lingkungan hidup tertuang secara jelas dalam ensiklik Laudato Si yang dikeluarkan oleh Paus Fransiskus pada tahun 2015. Menghadapi wajah bumi, rumah kita bersama, yang semakin rusak, Paus mengingatkan bahwa sejak awal "Allah melihat segala yang dijadikan-Nya itu, sungguh amat baik" (Kejadian 1:31). Sebagai ciptaan, manusia diberi kuasa bukan mengeksploitasi alam secara liar, melainkan menjaga dan memelihara. Menurut Paus, undangan Tuhan dalam kejadian 2:15 mengandung arti melindungi, menjaga, melestarikan dan merawat. Artinya ada relasi tanggung jawab timbal-balik antara manusia dan alam. Tanggung jawab itu mewajibkan manusia untuk menghormati hukum alam dan harmoni kehidupan dalam alam (Bdk. LS 6568)

Pandangan serupa dijumpai juga dalam Islam. Menurut Nawal Ammar, ajaran Islam tentang lingkungan hidup dapat ditemukan dalam konsep Islam mengenai tauhid (kesatuan). Dari perspektif tauhid, Islam mengajarkan bahwa Allah menciptakan alam dengan bersabda. Seluruh alam semesta adalah satu sistem tunggal yang diciptakan dan dipersatukan oleh Allah. Dalam sistem itu, hanya Tuhan yang memiliki ketergantungan khusus, sedangkan yang diciptakan saling bergantung satu sama lain dan bergantung pada Tuhan. Dalam relasi saling bergantung tersebut, Islam menempatkan pemeliharaan alam di bawah kuasa manusia sebagai khalifah di bumi. Sebagai khalifah, manusia bukan pemilik alam. Dia hanyalah penjaga yang bertanggung jawab mengelola dan memelihara alam. Tanggung jawab itu diberikan bukan karena manusia memiliki kualitas mahabaik, melainkan karena ia memiliki kemampuan khusus, yakni bernalar dan berbicara. ${ }^{35}$

Dengan latar ini, dapat dipahami mengapa Naess, juga banyak pemikir dan pejuang lingkungan hidup lain, seperti Thomas Berry, Al Gore, Fritjof Capra, mendasarkan pemikiran kosmologis mereka pada ajaran-ajaran agama (dan filsafat). Dasarnya, karena agama kaya akan ajaran-ajaran tentang alam, penciptaan alam, dan bagaimana seharusnya manusia membangun relasi harmonis dan saling menguntungkan dengan alam demi kebahagiaan bersama seluruh makhluk dan demi kemuliaan Tuhan.

\section{Agama: Penyebab Krisis Ekologis}

Selain menjadi sumber inspirasi dan pemberi arah bagi manusia dalam memandang dirinya, alam dan hubungan keduanya, agama dipandang juga, oleh Naess, sebagai akar atau

\footnotetext{
${ }^{34}$ Eric Katz, "Faith, God, and Nature, Judaism and Deep Ecology," in Deep Ecology and World Religions, New Essays on Sacred Ground, Edited by David Landis Barnhill and Roger S. Gottlieb (Albany, USA: State University of New York, 2001), 155.

${ }^{35}$ Nawal Ammar, "Islam and Deep Ecology," in Deep Ecology and World Religion, New Essays on Sacred Ground, Edited by David Barnhill and Roger S. Gottlieb (Albany, USA: State University of New York, 2001), 196-98.
} 
penyebab krisis ekologis. Menurut Naess, hal itu berakar teristimewa pada penafsiran atas teks-teks Alkitab yang cenderung bercorak antroposentrisme. Penafsiran ini menempatkan manusia seolah-olah sebagai pemilik alam dan karena itu merasa mempunyai hak untuk menguasai dan mengeksploitasi alam. Pandangan ini sesungguhnya bukan hal baru. Dalam tulisannya The Historical Roots of Our Ecological Crisis, Lynn White, Jr. bahkan dengan jelas menuduh teologi Kristen sebagai penyebab dominasi dan eksploitasi manusia atas alam. Inti pandangan White adalah penafsirannya atas Kejadian 2:8. Menurutnya, ayat itu dengan jelas mengandung pesan bahwa Tuhan telah memberikan kepada manusia kuasa untuk menata dan mengolah alam ciptaan semata-mata demi kebutuhan manusia. ${ }^{36}$

Argumen ini pula yang dipakai oleh penganut etika antroposentrisme. Sumber utamanya adalah Kitab Kejadian 1:26-28 tentang penciptaan. Dalam teks itu, dikisahkan bahwa Tuhan mengakhiri penciptaan alam semesta dengan menciptakan manusia. Kepada manusia, Tuhan memberikan kuasa untuk menguasai alam beserta isinya. Dalam perspektif paham antroposentrisme, kisah ini memberikan legitimasi yang kuat kepada manusia untuk mendominasi dan menaklukkan alam. Kewenangan ini ditafsirkan sebagai mengizinkan manusia untuk menguasai dan mengeksploitasi alam demi kelangsungan hidupnya semata. Dampaknya, alam menjadi rusak karena manusia berlaku seolah-olah sebagai pemilik dan penguasa atas alam.

Teks lain yang dirujuk adalah Kejadian 2:9 tentang kejatuhan manusia ke dalam dosa dan akibatnya. Dalam penafsiran antroposentrisme, sebelum jatuh ke dalam dosa, manusia adalah makhluk yang taat kepada kehendak Tuhan. Namun, setelah kejatuhan dalam dosa, secara otomatis manusia tidak lagi patuh kepada perintah dan kehendak Tuhan. Manusia taat sepenuhnya kepada kehendaknya sendiri. Ia memutuskan apa yang baik dan perlu untuk dikerjakan dan apa yang perlu dihindari. Dalam hubungannya alam, manusia mulai bekerja mengolah alam demi kepentingannya. Dalam upaya itu, manusia mulai membedakan mana makhluk yang perlu dijaga dan dipelihara karena bermanfaat bagi kehidupannya dan mana yang perlu dibasmi karena mengancam kelangsungan hidupnya. Campur tangan ini menyebabkan gangguan keseimbangan pada kehidupan alam dan pada gilirannya menciptakan krisis ekologis. ${ }^{37}$

\section{Perubahan Penafsiran Kitab Suci}

Mengatasi tendensi menjadikan agama sumber atau penyebab krisis ekologis, Naess berpandangan bahwa yang harus dilakukan adalah mengubah penafsiran biblis yang bercorak antroposentris dengan penafsiran yang lebih ekologis. Alasannya, pendekatan dari sisi ekologis menunjukkan sikap yang sama sekali berbeda. ${ }^{38}$ Naess menyebut beberapa teks sebagai contoh. Teks pertama ialah Kejadian 9:3. Dalam ayat ini, Tuhan memberikan "Segala sesuatu” kepada Nuh. “... Aku telah memberikan semuanya itu kepadamu seperti juga tumbuh-tumbuhan hijau." Ayat ini dapat ditafisirkan bahwa Allah mewariskan bumi

\footnotetext{
${ }^{36}$ Elspeth Whitney, “Lynn White, JR's The Historical Roots of Our Ecological Crisis After 50 Years," History Compass 13/8 (2015): 397.

${ }^{37}$ Barnabas Ohoiwutun, Posisi Dan Peran Manusia Dalam Alam Menurut Deep Ecology Arne Naess (Tanggapan Atas Kritik Al Gore) (Yogyakarta: Kanisius, 2019), 3-4.

${ }^{38}$ Naess, Ecology, Community and Lifestyle, 183.
} 
menjadi semacam milik pribadi. Namun, bagi Naess, "Penafsiran yang lebih masuk akal adalah Allah menempatkan segala sesuatu sebagai pemberian kepada Nuh dengan syarat khusus, yakni bahwa semua itu harus dipakai selaras dengan perintah Tuhan." ${ }^{39}$ Artinya, Nuh mendapatkan hak pakai atas bumi dan isinya tetapi bukan hak milik. Bumi dan isinya bukan milik manusia. Bumi hanya titipan bagi manusia untuk dipakai sesuai kehendak Tuhan.

Teks lebih egalitarian berasal dari Kejadian 1:21-22. Setelah Allah menciptakan segala jenis makhluk hidup, Allah melihat semua itu baik. Lalu, Ia memberkati semua makhluk dan mengizinkan mereka berkembang biak dan mengisi muka bumi. Penciptaan ini terjadi sebelum penciptaan Adam. Hal ini berarti setiap ciptaan memiliki nilai pada dirinya. Tidak satupun dari makhluk-makhluk itu diciptakan semata-mata hanya sebagai sarana. Tidak ada makhluk yang diciptakan hanya demi kepentingan manusia atau demi kepentingan makhluk lain. Pesannya jelas, yakni ada kesetaraan di dalam biosfer. Semua makhluk memiliki nilai pada dirinya dan memiliki hak yang setara untuk hidup dan berkembang.

Karena itu, Naess menyimpulkan bahwa penafsiran yang cocok adalah penafsiran yang memandang fungsi dan peran manusia sebagai penjaga dan pemelihara, sebagaimana ditulis dalam Kejadian. "Dan Tuhan Allah mengambil manusia itu, dan menempatkannya di dalam Taman Eden untuk mengusahakan dan memelihara taman itu" (Kej. 2.15). Ayat ini memerlihatkan dengan gamblang bahwa manusia harus bertanggung jawab atas segala aktivitasnya di atas bumi. Manusia harus menata agar tercipta keteraturan dan harmoni di dalam alam. Karena ia diciptakan tidak untuk memusnahkan melainkan untuk menjaga dan memelihara. Ia adalah penjaga, pemelihara, dan perawat alam. ${ }^{40}$

\section{Penutup}

Naess tidak memiliki definisi tertentu mengenai makna agama. Ia pun tidak menulis spesifik tentang agama. Namun, dari tulisan-tulsannya, terutama berkaitan dengan lingkungan hidup, dapat disimpulkan bahwa Naess memahami agama atas dua acara. Pertama, sebaga sumber inspirasi dan pedoman bertindak karena agama mengajarkan tentang makna alam, manusia, dan bagaimana seharusnya manusia membangun relasi dengan alam dan sesama. Hampir semua agama memiliki kekayaan ajaran dan tradisi terkait alam. Kedua, sebagai akar krisis ekologis. Hal ini bersumber teristimewa pada penafsiran atas teks-teks Kitab Suci karena penafsirannya cenderung bercorak antroposentrik yang menempatkan manusia sebagai penguasa mutlak atas alam. Konsekuensinya, alam jatuh dalam krisis karena dikuasai dan dieksploitasi tanpa belas kasihan. Demikian, mengatasinya jalan keluar yang perlu diambil adalah mengganti interpretasi kitab suci yang bercorak antroposentris dengan penafsiran yang bersifat ekologis karena cara pemahaman seperti ini akan membantu manusia untuk lebih menyadari dirinya sebagai stewardship alam.

\footnotetext{
${ }^{39}$ Terkutip dalam Ohoiwutun, Posisi Dan Peran Manusia, 193.

${ }^{40}$ Ohoiwutun, 193-94.
} 
B. Ohoiwutun - Agama dan Alam dari Perspektif Arne Naess: 1-12

\section{Daftar Pustaka}

Arne Naess. Ecology, Community and Lifestyle: Outline of an Ecosophy. 1. ed., Repr. Cambridge: Cambridge Univ. Press, 1998.

. "Gestalt Thinking and Buddhism." In The Ecology of Wisdom, Edited by Alan Drengson and Bill Devall. Berkeley: Counterpoint, 2008.

. Life's Philosophy. Georgia, USA: The University of Georgia Press, 2002.

. "Self Realization: An Ecological Approach to Being in the World." In The Ecology of Wisdom, Edited by Alan Drengson and Bill Devall. Berkeley: Counterpoint, 2009.

. "Spinoza and Attitudes Toward Nature." In The Selected Works of Arne Naess, Edited by Harold Glasser and Alan Drengson, Vol. X. The Netherlands: Springer, 2005.

. "Spinoza and the Deep Ecology Movement." In The Selected Works of Arne

Naess, Edited by Harold Glasser and Alan Drengson, Vol. X. The Netherlands:

Springer, 2005.

"The Basic of Deep Ecology Movement." In The Ecology of Wisdom, Edited by Alan Drengson and Bill Devall. Berkeley: Counterpoint, 2008.

"The Long-Range Deep Ecology Movement." In The Selected Works of Arne, Edited by Harold Glasser and Alan Drengson, Vol. X. The Netherlands: Springer, 2005.

Barnabas Ohoiwutun. Posisi Dan Peran Manusia Dalam Alam Menurut Deep Ecology Arne Naess (Tanggapan Atas Kritik Al Gore). Yogyakarta: Kanisius, 2019.

Deane Curtin. "A State of Mind Like Water: Ecosophy T and the Buddhist Tradition." In Beneath the Surface, Critical Essays in the Philosophy of Deep Ecology Edited by Eric Katz, Andrew Light and David Rothenberg. Cambridge, Massachusetts: The MIT Press, 2000.

Dylan Reaves. "Peter Berger and the Rise and Fall of the Theory of Secularization." Denison Journal of Religion 11, article 3 (2012): 11-19.

Elspeth Whitney. "Lynn White, JR's The Historical Roots of Our Ecological Crisis After 50 Years." History Compass 13/8 (2015).

Eric Katz. "Faith, God, and Nature, Judaism and Deep Ecology." In Deep Ecology and World Religions, New Essays on Sacred Ground, Edited by David Landis Barnhill and Roger S. Gottlieb. Albany, USA: State University of New York, 2001.

Gavin Flood. "Hindu Concepts," 2009.

https://www.bbc.co.uk/religion/religions/hinduism/concepts/concepts_1.shtml.

Henryk Skolimowski. Eco-Philosophy, Designing New Tactics Fo Living. London: Marion Boyars Publishers LTD, 1981.

Knut A. Jacobsen. "Bhagavadgita, Ecosophy T, and Deep Ecology.” In Beneath the Surface, Critical Essays in the Philosophy of Deep Ecology, Edited by Eric Katz, Andrew Light, and David Rothenberg. Cambridge, Massachusetts: The MIT Press, 2000.

Nawal Ammar. "Islam and Deep Ecology." In Deep Ecology and World Religion, New Essays on Sacred Ground, Edited by David Barnhill and Roger S. Gottlieb. Albany, USA: State University of New York, 2001. 